\title{
Deterrence and National Security in the Face of an Amorphous Threat
}

R. W. Werne

January 5, 2001

U.S. Department of Energy

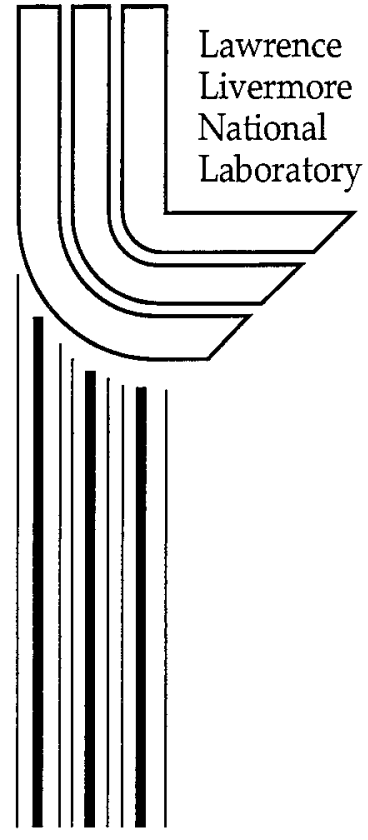




\section{DISCLAIMER}

This document was prepared as an account of work sponsored by an agency of the United States Government. Neither the United States Government nor the University of California nor any of their employees, makes any warranty, express or implied, or assumes any legal liability or responsibility for the accuracy, completeness, or usefulness of any information, apparatus, product, or process disclosed, or represents that its use would not infringe privately owned rights. Reference herein to any specific commercial product, process, or service by trade name, trademark, manufacturer, or otherwise, does not necessarily constitute or imply its endorsement, recommendation, or favoring by the United States Government or the University of California. The views and opinions of authors expressed herein do not necessarily state or reflect those of the United States Government or the University of California, and shall not be used for advertising or product endorsement purposes.

This work was performed under the auspices of the U.S. Department of Energy by the University of California, Lawrence Livermore National Laboratory under Contract No. W-7405-Eng-48.

This report has been reproduced directly from the best available copy.

Available to DOE and DOE contractors from the Office of Scientific and Technical Information

P.O. Box 62, Oak Ridge, TN 37831

Prices available from (423) 576-8401 http://apollo.osti.gov/bridge/

Available to the public from the National Technical Information Service

U.S. Department of Commerce 5285 Port Royal Rd., Springfield, VA 22161 http://www.ntis.gov/

OR

Lawrence Livermore National Laboratory Technical Information Department's Digital Library http://www.llnl.gov/tid/Library.html 


\title{
Deterrence and National Security in the Face of an Amorphous Threat
}

\author{
Roger W. Werne \\ Email:werne1@1lnl.gov \\ Nonproliferation, Arms Control and International Security \\ Lawrence Livermore National Laboratory \\ Livermore, CA 94550 \\ January 5, 2001
}

\section{Background}

The National Security threats that we face today and, in turn, the National Security requirements, are more diverse and complex than they were during the Cold War from 1945-1990. During that period, and bolstered by the experiences of World Wars I and II, US National Security policy was focused on the stabilization of post WW II country boundaries and containment of the Soviet block and China. The result was the bipolar world in which the nuclear and conventional forces of the United States, the Soviet Union, and their respective allies ensured a measure of political stability through a military stalemate of world wide proportions. The practical result was that large scale changes in national borders were unlikely, but internal conflict within countries, and local conflicts between neighboring countries could still occur, albeit with participation from one or both of the Superpower camps. US National Security Policy was designed primarily for stabilization of the bipolar world on the military front and for competition with the Soviet Union and China on economic and political fronts.

\section{Today's Threats}

The collapse of the Soviet Union changed the global picture. The bipolar world and its military stalemate appear to be gone for the moment and the threat which was the foundation for US National Security policy has changed significantly. Some will argue that China has intentions of replacing the Soviet Union as a military superpower and thus recreate the bipolar world. Furthermore, Russia still has significant nuclear forces and has recently talked of lowering the nuclear threshold in an apparent attempt to make up for its weakened conventional forces. Clearly the threat of large scale nuclear war is much reduced, but not gone entirely.

Having acknowledged the Chinese and Russian threats, what does the global picture look like today? The boundaries of most countries are secure but there are significant frictions, that have, or could lead, to armed conflict. Most of these are today's manifestations of long standing problems with no easy solution in sight. It can be argued that most local conflicts will be of no direct threat to US interests. However there are situations where local conflict can have significant international impact if left unchecked. For example localized conflict in the Middle East could affect oil supplies world wide, open conflict between China and Taiwan could draw in Japan and the United States, India and Pakistan have armed conflict over Kashmir threatening a nuclear exchange, and 
North Korea continues to be a concern with its long range missile and nuclear and CBW development programs.

There is also the problem of state sponsored or sanctioned terrorism against the US and its allies. As with Korea, a number of countries have been identified as having had, or still having, active chemical, biological, and nuclear weapons programs along with strategic missile programs that would enable them to deliver warheads to the US mainland or similarly threaten US allies. Furthermore the problem of the clandestine delivery of a weapon of mass destruction designed to target US civilian population centers is very real. Such threats designed to deter US policy initiatives abroad, have been termed "asymmetric" warfare and appear to be an emerging capability in a number of countries.

\section{The Response}

One of the major problems facing National Security policy makers is that some the threat scenarios discussed above are long standing remnants of the cold war and require continued attention. Others are more amorphous in their nature, such as the WMD terrorist threat, and can and probably will change on time scales that are short compared to a decade. The threats against which we are attempting to defend ourselves are ill defined in detail and are not static in time. Therefore the important question to address becomes: what National Security policy initiatives can be implemented that will span the spectrum of threats we are likely to face in the future? I suggest that there are five elements within a US National Security Program that would enable the US to prepare for, deter and respond to those threats. These are broad elements, whose detail will depend on the probable long and near term threats, but which are flexible enough to respond to the breadth of what we are likely to face. They are as follows.

1. Be Second to None in Nuclear Weapons: As long as nuclear weapons exist the US must be capable of deterring nuclear weapon intimidation. Being "second to none" is a relative term and can be the case whether we have 5000 weapons or 500 weapons. It depends on the nuclear weapon capability of our adversaries. So continuing to negotiate treaties that downsize the relative sizes of the US and Russian stockpiles with due regard to other nuclear forces worldwide may be acceptable.

Being a leader in any subject means that you must know more about that subject than your competitors and be capable of "meeting and beating" the competition if challenged. Therefore the US must maintain a nuclear weapons readiness program that will ensure that we could appropriately respond to any attempt by another country to design, test, manufacture and deploy nuclear weapons that would enable them to gain a real or perceived advantage over the US.

2. Make the World More Transparent: Avoiding surprise is one of the keys to successful deterrence. To prepare for eventualities that may threaten US interests requires preparation and forewarning. The US must have a superior intelligence and analysis capability. This means that to the maximum extent possible, we can "monitor" those who would threaten the US and its Allies. This will involve all of the traditional 
forms of intelligence gathering and the ability to monitor the internet. Many terrorist organizations are dispersed and use the internet and other modern communication technologies as the "tie that binds". To the extent that we are forewarned of the intentions of our adversaries we can prepare and respond accordingly.

3. Precision Force Projection: The ability to strike when necessary with sufficient force and precision to accomplish a goal and to do so with minimum casualties and collateral damage is the requirement. This force projection may range in size from major a tactical initiative such as in Kuwait to small efforts involving only a few assets. Force projection does not necessarily have to be physical force. Disruption of communications, command and control is also part of the equation. Therefore "Information Superiority" in both an offensive(control theirs) and defensive(protect ours) becomes a new element of force projection.

4. Home Land Defense: There are a range of possible defenses that the US can develop and deploy based upon the threat and political will. These range from national missile defense, to preparation of the civilian medical infrastructure to deal with a clandestinely delivered biological weapon, to a disruption of food, water and energy sources. For example in the case of a clandestine biological attack, local hospitals would likely be the first to diagnose a disease outbreak and would need to be reinforced to deal with the situation.

5. Cooperative Threat Reduction: Measures that increase confidence and trust between two real or potential adversaries and therefore eliminate threats are important. Examples of threat reduction initiatives between the nuclear super powers are the UGT treaty protocols, START II, the downsizing of special nuclear materials stockpiles, and the Nuclear Cities Initiative. Cooperative efforts such as the IAEA and International export controls on militarily important technologies are good example of cooperative threat reduction on the International scale.

It is clear that many important details need to be added to the above. In particular the details of Response are in large part dictated by the details of the probable threats. Therefore understanding the threats we face is important. For example the US has a great deal of understanding about the nuclear threat whether it be strategic, tactical or terrorist. And appropriate safeguards are in place and more may be needed depending on one's beliefs about the threat. However our understanding of the biological weapon threat and how to respond to it is much less complete. Much more research on that subject is needed because it is easy to imagine horrific bio-terrorist events which seem plausible, but which may be more difficult to execute than would seem at first blush. To the contrary, perhaps some scenarios are as bad as they appear. More analysis of the threat needs to be undertaken before the US can plan a balanced and intelligent response.

Acknowledgements- I would like to thank many people within NAI whose enlightening discussions made this note possible particularly Mike Carter who suggested the need for 
a section on Home Land Defense and Jeff Richardson for the suggestion on Cooperative Threat Reduction. 